\title{
СІЛЬСЬКОГОСПОДАРСЬКІ ТОВАРИСТВА І ФОРМУВАННЯ ОСВІТНЬО-КУЛЬТУРНОГО ПРОСТОРУ УКРАЇНСЬКИХ ГУБЕРНІЙ РОСІЙСЬКОЇ ІМПЕРІЇ (1861-1917 РР.)
}

\author{
М. С. Лисенко
}

Лисенко М. С. Сільськогосподарські товариства і формування освітньо-культурного простору українських губерній Російської імперії (1861-1917 рр.). У статті розкривається вплив сільськогосподарських товариств на зміни у аграрній галузі українських губерній Російської імперії. Охарактеризовано значення європейських ідей у формуванні основних засад сільськогосподарської освіти, дослідних установ. Висвітлено просвітницьку діяльність громадських організацій та їх роль у культурницькому процесі.

Ключові слова: сільськогосподарські товариства; українські губернії; Російська імперія; сільське господарство; аграрні навчальні заклади, дослідницькі установи; просвітництво.

Лысенко М. С. Сельскохозяйственные общества и формирование образовательно-культурного пространства украинских губерний Российской империи (1861-1917 рр.). В статье раскрывается влияние сельскохозяйственных обществ на преобразования в аграрной отрасли украинских губерний Российской империи. Охарактеризовано значение европейских идей в формировании базовых основ сельскохозяйственного образования, опытных учреждений. Исследованы просветительская деятельность общественных организаций и их роль в культурном процессе.

Ключевые слова: сельскохозяйственные общества; украинские губернии; Российская империя; сельское хозяйство; аграрные учебные заведения; опытное дело; просвещение.

Lysenko M. S. Agricultural Societies and Formation of the Educational and Cultural Space of the Ukrainian Provinces of the Russian Empire (1861-1917). The article reveals the influence of agricultural societies on the transformation in the agrarian sector of the Ukrainian provinces of the Russian Empire. The importance of European ideas in shaping the basic foundations of agricultural education, experienced institutions is characterized. The educational activity of public organizations and their role in the cultural process was studied.

Keywords: agricultural societies; Ukrainian provinces; Russian Empire; agriculture; agrarian educational institutions; experienced institutions; cultural enlightenment.

Поява і діяльність сільськогосподарських товариств (далі сгт) припадає на XIX ст. Вони були громадськими об’єднаннями. Метою їх створення стало сприяння розвитку сільського господарства в країні. С2m підпорядковувались Міністерству Землеробства Російської імперії. Заснування мережі аграрних організацій було зумовлено потребами певних верств населення відстоювати свої інтереси та права. Цей суспільний рух мав загальнодержавний характер, став наслідком пореформених змін в українських губерніях. Поштовхом для об’єднання у товариства потрібно назвати передусім економічні фактори: проблеми внутрішньої та зовнішньої торгівлі, транспорту, ринку найманої праці, збуту, неврожайні роки і т. ін. Довгий час не існувало місцевих сільськогосподарських органів, що могли вчасно, ефективно і швидко вирішувати проблеми на місцях. Все це спонукало земельних власників створювати галузеві товариства. Вищезгадана категорія населення психологічно і соціально була найбільш підготовлена до реформ. На формування їхніх поглядів та світогляду впливали європейський досвід та відрядження за кордон.

Хронологічні межі дослідження - період з 1861 по 1917 рр. Нижня межа пов’язана 3 періодом проведення реформ у Російській імперії та скасуванням кріпацтва. Верхня межа визначається початком Лютневої революції. Територіальні межі дослідження охоплюють українські губернії Російської імперії у досліджуваний період.

Тема сгт отримала певне висвітлення у літературі. Умовно історіографію проблеми варто поділити на декілька етапів: 1) дореволюційний; 2) радянський; 3) сучасний. У дореволюційний період виходять у світ перші роботи. У них розглядаються поточні справи використання зарубіжної практики у вітчизняних господарствах. Публікації висвітлюють 
результати діяльності дослідних полів або ферм, подають оглядові нариси по окремим губерніям ${ }^{1}$. У радянській період вплив європейських ідей на розвиток аграрної галузі українських губерній не вивчався. Крім того, в радянській науці практично відсутні розвідки про cгm. На сучасному етапі дослідники намагаються висвітлювати різні аспекти цього багатопланового процесу. Більшість вчених вивчає європеїзацію періоду реформ під кутом зору історії науки і техніки. Однак низка питань залишається поза увагою².

Становлення вітчизняного сільського господарства та освіти проходило у контексті європейського досвіду. У Західній Свропі необхідність підвищення ефективності аграрної сфери вже у першій половині XIX ст. потребувала використовувати нові знання, техніку та технології. Культурне піднесення й економічний розвиток європейських країн сприяли вдосконаленню системи аграрної освіти, поширенню наукових агрономічних знань. На розвиток сільськогосподарської науки та освіти безпосередньо вплинули успіхи природознавства і технічний прогрес у промисловості. За зразок для створення системи аграрних закладів та установ в Україні взяли німецьку модель.

Першими провідниками знань у аграрній галузі Німеччини стали вищі навчальні заклади. У 1727 році при університеті в Галле почали викладати сільське господарство як окрему науку. Згодом таку спеціальність було введено і в інших навчальних закладах. У 1912 році у Німеччині нараховувалось десять аграрних вишів. У цій країні були також організовані сільськогосподарські заклади інших рівнів. Зокрема, 22 середні, 57 нижчих та 193 зимових аграрних шкіл ${ }^{3}$. В останньому типі навчались діти селян, що закінчили початкові училища. Школи були недорогими і зручними для учнів та їхніх батьків. Навчання у школах продовжувалося дві зими й не заважало сезонним польовим роботам. Крім того, у Німеччині була створена значна кількість «додаткових» сільськогосподарських зимових шкіл. Подібні школи підвищували кваліфікацію колишніх учнів. Такий підхід виявився раціональним. Система сільськогосподарської освіти була доступною для більшості населення. Вона сприяла високому рівню розвитку аграрної галузі держави. Нарешті, на початку XX ст. Німеччина, Австро-Угорщина та Швейцарія проводили спільні заходи. На загальне населення вищезгаданих країн 96 млн чол. функціонувало 15 лісних та сільськогосподарських академій, а також лісні відділення при трьох університетах ${ }^{4}$. Позитивний німецький досвід певною мірою був перенесений в Україну.

Діячі сгт українських губерній окремі ідеї для розвитку сільського господарства брали й в інших європейських країнах (передусім Франції, Італії), а також використовували успішну заокеанську практику США. Цей вплив розповсюдився у кількох сферах. У першу чергу у відкритті сільськогосподарських навчальних закладів, дослідній і просвітницькій роботі.

Загальний розвиток ринкових відносин після реформ 60-80-х рр. XIX ст. у Російській імперії, аграрна спрямованість економіки українських губерній та ії залежність від продуктивності землеробства потребувала поліпшення аграрної культури. Заради майбутнього прогресу доцільно було відкривати навчальні заклади, дослідні установи та проводити культурницьку роботу.

Освіта. Система сільськогосподарської освіти імперської Росії мала свою специфіку. Важливість створення аграрної освіти в країні була усвідомлена та втілена у життя дещо пізно (у порівнянні з Свропою). Становленню освіти сприяли сгт, земства і приватні особи. Державою цю галузь фінансувалася недостатньо. Число сільськогосподарських шкіл у Російській імперії було незначним, якщо порівнювати із кількістю землеробського населення країни. До речі проблемною була не тільки фахова, а й загальна освіта.

У XIX ст. на території України започаткували систему аграрної освіти. Найбільш інтенсивно розвивалась нижча аграрна освіта. До неї входили сільськогосподарські училища, загальні сільськогосподарські школи I та II розрядів, спеціальні сільськогосподарські школи (садівництва, виноградарства, городництва, лісорозведення тощо), практичні аграрні школи, різні курси та класи.

Середня аграрна освіта була представлена незначною кількістю навчальних закладів. До них відносились Уманське училище садівництва і землеробства, Харківське сільськогосподарське училище, Нікітське училище садівництва та виноробства, Херсонське сільськогосподарське училище $\mathrm{e}^{5}$. Їх діяльність дала поштовх і створила умови для подальшого розвитку вищої аграрної освіти. 
25 вересня 1816 року був відкритий аграрний університет у передмісті Варшави - Маримонті. Він називався Маримонтським інститутом земельного господарства. У 1840 році до нього було приєднано Варшавську лісову школу. Навчальний заклад реорганізували у Маримонтський інститут сільського господарства та лісівництва. У 1862 році інститут було переведено до м. Нова Олександрія. Він продовжував свою діяльність як Новоолександрійський інститут сільського господарства та лісівництва до початку Першої світової війни. У 1914 році інститут було евакуйовано до м. Харкова ${ }^{6}$. Завдяки зусиллям Харківського товариства сільського господарства і сільськогосподарської промисловості вуз залишився у цьому місті й був перейменований у Харківський аграрний університет. Сьогодні навчальний заклад вважається першим аграрним вишем в Україні.

Вищу аграрну школу у досліджуваний період представлено також спеціальними відділеннями і факультетами в політехнічних інститутах. У Київському політехнічному інституті, відкритому у 1898 році, працювало сільськогосподарське відділення. Воно вело підготовку агрономів. До складу Харківського технологічного інституту спочатку входило два факультети - механічний та хімічний. У 1895 році у зв'язку з необхідністю забезпечення спеціалістами машинобудівних заводів було відкрито кафедру сільськогосподарського машинобудування. Тоді ж запланували підготовку інженерів відповідного профілю. Пізніше кафедра перетворилася на відділення сільськогосподарського машинобудування .

Київське сільськогосподарське товариство брало безпосередню участь у відкритті Політехнічного інституту у Києві, що мав агарне відділення. На Правобережній Україні завдяки зусиллям сгт були відкриті чотири навчальні заклади: сільськогосподарські курси Київського товариства сільського господарства і сільськогосподарської промисловості (1901 р., м. Київ); Боярська школа рільництва I розряду (1902 р., ст. Боярка), Гуменська практична школа садівництва й сільського господарства (1902 р., Волинська губ.) та Житомирська школа садових робітників (1909р., Волинська губ. $)^{8}$. Імператорське товариство сільського господарства (м. Одеса) співпрацювало з викладачами аграрного відділення Новоросійського університету.

Сәт опікувалися агарними навчальними закладами і після їх відкриття. Вони певною мірою їх фінансували, допомагали талановитим студентам та учням, нагороджували переможців різних конкурсів, організовували поїздки і підвищення кваліфікації за кордон, працевлаштовували у господарства приватних маєтків 9 .

Дослідна справа, що виникла 3 потреб господарства, виробництва, має свою традицію. Важким і тривалим практичним досвідом людина усвідомлювала корисність вдосконалення обробітку землі, угноєння, покращення порід свійських тварин тощо. Наука про сільське господарство зародилася в Свропі у XIX ст. Вона мала своїм фундаментом успіхи природознавства, експерименти у рослинництві, вивчення грунтів тощо. Позитивний вплив на розвиток дослідної справи в Україні набув досвід іноземних держав, передусім Німеччини. У цій країні Саксонське сгт організувало у 1852 році поблизу Лейпцига першу дослідну станцію своїм коштом. Характерною рисою німецьких дослідних станцій була свобода у визначені тематики дослідження. Від директора установи залежали напрями наукових розробок ${ }^{10}$.

В українських губерніях Російської імперії наприкінці XIX ст. домінувала парова система у рільництві, з трипільною сівозміною та застосуванням перегною, що панувала в Європі ще на початку століття. Для того, щоб перейти до інших систем господарювання, запровадити нові сорти рослин, породи тварин, вводили у практику більш досконалі агротехнічні прийоми, поступово використовували європейський досвід. Ставилося питання й про організацію сільськогосподарської дослідницької справи.

Після скасування кріпосного права відкрилися можливості для капіталістичного розвитку сільського господарства в Україні. Передусім із застосуванням складних машин, мінеральних добрив, високоякісних порід домашніх тварин тощо. Нераціональне використання землі збільшило вплив посух на врожайність культур, особливо у степовому регіоні України. У ХІХ ст. зареєстровано 40 посушливих років, наслідки яких були важкими. Індивідуальні сільські господарства не могли самі усунути ці негаразди й вести прогресивне господарство. Погляди мислячих людей (серед них було багато поміщиків, земців, чиновників) звернулися до науки. Поступово збільшилась кількість та підвищилась кваліфікація вітчизняних наукових кадрів. 
У Російській імперії державні структури мали значний вплив у справі організації сільськогосподарських дослідних установ. Міністерство землеробства спрямовувало майже всі питання, пов'язані з дослідною справою. До них можемо віднести визначення основних типів дослідних установ, їх функції, завдання, програми і методи дослідження, облаштування, штат співробітників, обсяги і джерела фінансування. Дослідна справа засновувалась за окремими природно-історичними районами. Основними вадами дослідної справи пореформеної Росії були неузгодженість роботи різних дослідних установ, навіть у межах одного грунтово-кліматичного району. Крім того, справа була новою. Тому державні органи небезпідставно розраховувала на ентузіазм та підтримку на місцях.

Одна з перших дослідних установ у Російській імперії (крім раніше створених дослідних казенних ферм, де проводились у тому числі сільськогосподарські спостереження та досліди) відкрилась у 1830 р. у Горках (Білорусія) при Горигорецькому рільничому інституті. Пізніше організовано контрольну дослідну станцію при Ризькому політехнічному училищі (1864р.), станцію для випробування насіння при Імператорському Ботанічному садові у Петербурзі (1877р.), дослідні поля при Петровській Академії (1877р.), у казенному маєтку «Петергоф» у передмісті Риги, подарованому Ризькому політехнічному училищу для організації зразкової ферми (1879 р.) та Новоолександрійському інституті сільського господарства та лісівництва ${ }^{11}$. В українських губерніях дослідні поля і станції засновувались також сгт, земствами та приватними особами.

На початку XX ст. Департаментом землеробства було запропоновано проект порайонного вивчення сільського господарства (підготовлений агрономом В. В. Вінером) ${ }^{12}$. У Свропейській Росії (разом з Кавказом) виокремили 27 сільськогосподарських районів за природно-історичними ознаками. У кожному із них, крім дослідних станцій, що організовувались згідно урядовому проекту, планувалось заснувати мережу дослідних установ для всебічного вивчення питань продуктивності рільництва. Усі витрати за створення та утримання районних й обласних станцій (вони повинні були обслуговувати великі райони в кілька губерній) Міністерство землеробства планувало взяти на себе. Проте сільськогосподарська комісія Державної Думи вирішила активно залучати місцеву ініціативу (cгm, земства, приватних осіб) та їхні фінансові засоби. Субсидії для відповідних закладів встановили у розмірі 75\% загальних витрат. Проект Вільного економічного товариства з вивчення мінеральних добрив у 1867 році під керівництвом Д. І. Менделєєва був схвалений урядом і суспільством.

У досліджуваний період працювало декілька типів дослідних установ: дослідні станції (загальні, спеціальні, I та II розряду, контрольні), дослідні поля і господарства (іноді їх називають зразковими хуторами або дослідними фермами), показові або демонстраційні поля і ділянки, колективні досліди та мережа дослідних ділянок. Для розповсюдження корисної інформації, пропагування нових прогресивних знань при дослідних установах для населення проводилися публічні лекції, створювалися спеціальні курси з різних галузей сільського господарства відповідно програмам, затвердженим Міністерством землеробства.

Значну роль у розвитку сільськогосподарської дослідної справи в Україні наприкінці XIX ст. - початку XX ст. відіграло Харківське сгт та його активний член професор Харківського університету А. Є. Зайкевич (1842-1931рр.). За період 1881-1902 рр. А. С. Зайкевич став ініціатором заснування 37 дослідних полів. Найдовше існувало Морочанське дослідне поле (12 років), Новотаволжанське (10 років), Тростянецьке та Білоколодязне по шість років, інші - по одному року ${ }^{13}$. Така незначна тривалість існування пояснювалась нестачею коштів, відсутністю довгострокового планування у цій справі. Протягом 1886-1890 pp. за ініціативою та коштом громадських організацій засновано шість дослідних установ. До 1910 року їх нараховувалось вже 24. Поступово збільшувались асигнування на дослідні установи. Цим переймалися не лише сгт, але й земства та уряд. Земці співпрацювали з сгт. Так, Департамент землеробства у 1906 році виділив 549,8 тис. руб., а у 1914 році - 4587,7 тис. руб. на дослідну справу ${ }^{14}$. Завдячуючи такій цілеспрямованій політиці Департаменту Землеробства на початку XX ст. спостерігався потужний розвиток місцевих дослідних установ. Певною мірою був знайдений консенсус між державними потребами і місцевою ініціативою. Увагу до дослідницьких установ привернула Всеросійська нарада $з$ дослідної справи 1908 року. Після неї у країні була проведена низка обласних та місцевих нарад. Це позитивно впливало на розробку і прийняття планів дослідницьких установ, об'єднання у великі обласні організації. 
Позитивним моментом була співпраця з приватними власниками (передусім поміщиками, що володіли «міцними» господарствами) і їх дозвіл проводити роботи у своїх маєтках. Наприклад, у Харківській губернії у господарствах П. І. Харитоненка ${ }^{15}$.

Особливості функціонування дослідних установ по регіонах. Приватні дослідні станції. На Правобережній Україні сгт заснували пізніше, тому робота велася через філії загальноросійських товариств. Дослідна справа у регіоні проводилась різними установами. До них потрібно віднести Київську агрономічну лабораторію Південно-Російського товариства заохочення землеробства і сільської промисловості та Миронівську станцію Всеросійського товариства цукрозаводчиків. Три товариства краю (Південно-Російське товариство заохочення землеробства і сільської промисловості, Всеросійське товариство цукрозаводчиків та Подільське сәт) включали ентомологічні станції. $311 \mathrm{czm}$ Росії, що мали дослідні установи, які дорівнювалися Департаментом землеробства до дослідних станцій, три знаходились у Південно-Західному краї й структурно входили до Подільського, Київського та Умансько-Липовецького товариств. У 1915 році у Південно-Західному краї 13 товариств мали по одному або мережу дослідних полів, у тому числі чотири сгm проводили колективні досліди і польові спостереження ${ }^{16}$.

Якщо охарактеризувати систему роботи таких установ регіону, то варто виділити їх вузьку спеціалізацію (передусім з рільництва та культури цукрового буряку). Програма дослідних полів охоплювала такі питання: застосування добрив; використання різних типів сівозмін; дослідження впливу на врожайність польових культур різних способів обробітку грунтів; вивчення різних прийомів сівби; насінництво основних сортів сільськогосподарських культур; застосування нових кормових рослин; методи боротьби 3 посухою. Найбільше уваги приділяли використанню мінеральних добрив.

Процес формування мережі та діяльність наукових установ на Київщині відбувався також інтенсивно. До 1917 р. у Київській губернії працювало 16 дослідних установ. Серед них дві загального профілю: дослідні станції (Радомишльська та Київська), чотири спеціальні (дві контрольно-насіннєві, одна дослідно-селекційна і одна ентомологічна) ${ }^{17}$.

Фінансове становище аграрних дослідних установ на Київщині було складним. Приватні дослідні установи існували за рахунок окремих господарств і частково підтримувались земствами.

Отже, перші дослідні установи відрізнялись нетривалим терміном існування та недоліками організаційного характеру. Однак вони зробили вагомий внесок у становлення вітчизняної дослідної справи, надання практичних рекомендацій товаровиробникам.

Соціально-економічні передумови зародження сільськогосподарської дослідної справи на Поділлі. Передові подільські господарі, прагнучи до згуртування громадських зусиль на терені сільського господарства, довгий час були позбавлені змоги створити свої місцеві сгт. Тому вони здійснювали широке співробітництво з загальноросійськими сzт, організаціями природознавців і навіть технічними товариствами. До таких активних громадських організацій належали Вільне економічне товариство, Імператорське Московське cгm, Імператорське сгт Південної Росії, Київське та Подільське товариства природознавців, Імператорське Російське технічне товариство (Київське та Одеське відділення). Вони стали ініціаторами видання перших часописів у країні, ініціювали спеціальні природознавчі, аграрні, промислові дослідження різних регіонів країни, у т.ч. українських губерній. Напрацювання цих та інших об'єднань, контакти з їхніми членами дали змогу нагромадити певний досвід місцевих сгт. До них варто віднести Київське (1874р.), Подільське (1896 р.), Умансько-Липовецьке (1901р.) сгт, Київське агрономічне товариство (1909р.). Вони стали активними співорганізаторами галузевих дослідних установ. Успішним проектом Київського сгт було заснування Деребчинського дослідного поля в Ямпільському повіті (власник барон А. А. Маас), яке діяло протягом 1888-1898 рр. Головним напрямом дослідних робіт установи було вивчення питання ефективності використання добрив. Наукова робота у різні роки здійснювалась В. Г. Ротмістровим, Ф. Л. Любанським та іншими вченими під загальним керівництвом професора С. М. Богданова ${ }^{18}$.

При Подільському сгт працювала Подільська дослідна станція з мережею постійних та тимчасових дослідних полів (1901р.), контрольною станцією (1904р.), Гуменською практичною нижчою школою садівництва і сільського господарства (1902 р. $)^{19}$. Головною метою дослідної справи стало сортовипробування (більше, ніж 200 сортів сільськогос- 
подарських культур) та грунтово-кліматичних умов. На сторінках власного друкованого періодичного видання «Справочный листок Подольского общества сельского хозяйства и сельскохозяйственной промышленности» (пізніше воно називалося «Справочный листок») та інших галузевих часописів виходили в світ наукові праці членів товариств - науковців І. А. Лец-Запартовича, Ф. Л. Любанського, В. М. Сведерського та інших.

Поділля залишалося специфічним соціально-економічним регіоном України. Це вплинуло на особливості становлення галузевого дослідництва у краї. Загальний розвиток ринкових відносин після реформ 60-80-х рр. XIX ст. у Росії, аграрна спрямованість економіки регіону та їі залежність від продуктивності землеробства, спеціалізація краю на вирощуванні пшениці та цукрового буряку потребували покращення агрокультури. Перенаселення регіону, малоземелля, швидкі темпи й обсяги розорювання земель вимагали переходу до інтенсивних форм господарювання. Найбільш потужною галуззю промисловості була цукрова. Господарства стали не тільки замовниками та ініціаторами наукових досліджень, а й центром поширення наукових знань серед населення. В селянських господарствах поступово поліпшувався фонд вирощуваних польових культур. Активніше застосовувались мінеральні добрива. На базі маєтків створювались перші метеорологічні та агрономічні станції, проводились досліди з вигодовування худоби. Розширення транспортної мережі, особливо залізничної, дало поштовх розвитку цукрової промисловості, покращенню зернового господарства. Воно також сприяло виходу регіону на світові ринки, зміцненню наукових та виробничих зв'язків. Концентрація великого приватного капіталу в руках місцевих землевласників (переважно поляків) давала можливість фінансувати сільськогосподарські дослідні установи.

Приватні землевласники ініціювали дослідження у галузі сільського господарства на Поділлі. Спеціалізація краю на виробництві цукрового буряку обумовила значну потребу у насінні цієї сільськогосподарської культури. Вона стимулювала інтерес до створення власного насіннєвого фонду, відкритті дослідних селекційних установ при господарствах. Так було започатковано селекційну науку у регіоні. У 70-х pp. XIX ст. на території українських губерній утворились перші насіннєві господарства, що займалися селекцією цукрового буряку. До них відносимо підприємства Б. С. Старорипинського у с. Мала Карабчіївка Кам'янецького повіту та графа Л. Ф. Валькова у м. Калинівці Вінницького повіту Подільської губерніїํ․ Провідні вітчизняні вчені того часу С. М. Богданов, Ф. К. Куделька, Д. І. Кірсанов проводили досліди у них. Вчені доводили, що грунтово-кліматичні умови українських земель сприяють вирощуванню цукрового буряку та отриманню його насіння високої якості. Вперше Поділля заявило про себе як про виробника нових сортів та їхнього насіння не тільки у межах Російської імперії, а й на аграрних ринках західних країн. За допомогою селекції були виведені місцеві сорти, що давали гарні врожаї.

На рубежі XIX-XX ст. у Подільській губернії існувало 27 насіннєвих господарств, що проводили селекційну роботу. Найвідомішими за масштабом дослідних селекційних робіт були господарства К. С. Бущинського та М. М. Лонжинського, що знаходилось у маєтку Немерче Могилівського повіту (1886р.); Уладівська селекційна станція Вінницького повіту графа П. Ф. Потоцького (1888р.). Досліди з сортами проводили при найбільших у губернії цукрових заводах (Чечельницькому, Ялтушківському, Степанівському, Товаристві цукрових заводів «Городок») $)^{21}$.

Приватна ініціатива постала і біля витоків метеорології у краї. Всі великі насіннєво-селекційні господарства губернії мали метеорологічні станції, результати роботи яких використовували у повсякденній практиці. У галузі тваринництва дослідницька робота здійснювалась на зразковому рівні у 60 подільських господарствах. Найвідомішим 3 них було Тележинське племінне господарство Літинського повіту, яке належало К. К. Дорожинському ${ }^{22}$.

Варто згадати про приватні помологічні установи. Наприклад, помологічні станції у маєтках «Окна» Балтського повіту князя А. С. Гагаріна (1875 р.), «Осламове» Новоушицького повіту графа О. О. Шміта (1881р.), помологічний сад у м. Вінниця Я. Й. Немєца $(1889 \text { р. })^{23}$. Дослідники прагнули розширити асортимент вирощуваних плодових культур регіону, адаптувати закордонні сорти та збільшити їх урожайність в умовах місцевого клімату. Лише такої культури, як яблуня, було виведено більше десяти нових сортів. Найкращим визнали сорт Джонатан. Напрацювання подільських помологів заклали основу 
розвитку промислового садівництва у регіоні. Місцеві товаровиробники збували свою продукцію у російські столиці і Європу.

Плотянська сільськогосподарська станція князя П. П. Трубецького на Поділлі - одна 3 найбільших дослідних установ Російської імперії, що існувала 20 років (1894-1914 pp. $)^{24}$. На ній проводились систематичні дослідження, спрямовані на подолання залежності врожаю від посушливого клімату. На цій станції працювали такі відомі у майбутньому вчені Як П. О. Бичихін, Ф. Б. Яновчик, О. Г. Карабєтов та інші. Приватні експерименти у дослідних господарствах маєтків (землевласників та аристократії) варто розглядати як складову вітчизняної агрономії досліджуваного періоду. Набув вагомості рух раціонального господарювання. Це тісно пов'язано з усвідомленням важливості науки для прогресу сільського господарства. Певною мірою це була і «мода» на зразкові господарства. Хоча на першому місці завжди залишалась прибутковість маєтків. У поточний процес залучились велике коло подільських поміщиків - від збіднілої польської шляхти до російської аристократії.

Отже, специфіка внутрішньої політики, що здійснювалась на території Південно-Західного краю, виявилась в упередженому ставленні до громадських ініціатив. Тут пізніше був отриманий дозвіл на функціонування сгm, земства дозволені лише у 1911 році. Разом вони мали піклуватися про аграрну допомогу населенню. На Поділлі були відсутні вищі і середні сільськогосподарські навчальні заклади, які у західних країнах ставали центрами наукових знань в агрономії і тваринництві. Дослідна справа була одним із напрямків роботи подільських сгт. Їх діяльність сприяла грунтовним дослідженням. Результати досліджень використовувались у різних галузях сільського господарства. Усі культурні починання потребували знання місцевих умов. Поставлену задачу було виконано.

Яскравим прикладом прогресивних змін у сільському господарстві потрібно назвати дослідні установи Полтавщини, що функціонували в кінці XIX - на початку XX ст. На полтавських теренах цей процес відбувався досить інтенсивно (зважаючи на аграрний характер економіки регіону). Вони стали ініціаторами порайонного вивчення сільського господарства держави.

Через брак матеріальних коштів питання організації дослідної установи вирішувалось впродовж 16 років. Лише 28 жовтня (10 листопада) 1884 року Полтавське сгт обрало першу раду дослідного поля, таким чином започаткувавши його. Зусиллями директорів Б. П. Черепахіна, В. М. Дякова, Ю. Ю. Соколовського та інших поступово збільшувався обсяг дослідницько-виробничої роботи. 31910 року Полтавське дослідне поле працювало як сільськогосподарська дослідна станція із статусом центральної установи цілої мережі дослідних полів ${ }^{25}$. Організація наступних дослідницьких установ у Полтавській губернії не зустрічала перешкод, оскільки була доведена доцільність подібних закладів. До 1907 року у регіоні були створені Лохвицька дослідна тютюнова плантація (1890р.), Золотоніське (1898р.), Андріївське (1902 р.), Роменське (1905 р.) та Прилуцьке (1907 р.) дослідні поля. На 1913 рік у Полтавській губернії налічувалось 13 дослідних установ. Вони підпорядковувались: 6 - сәт, 6 - Полтавському губернському земству, 1 - повітовому земству ${ }^{26}$.

Таким чином, становлення сільськогосподарської дослідної справи в українських губерніях Російської імперії почалося у другій половині XIX ст. Було знайдено вдале співвідношення теорії та практики. Це сприяло збільшенню їх чисельності, масштабів дослідження та обсягів фінансування. На початок XX ст. у межах досліджуваного регіону існували дослідні установи декількох типів: дослідні станції, поля, ферми, показові та демонстраційні поля і господарства. Значну роль у справі заснування аграрних дослідних установ відіграли сгт.

Поєднання теорії та практики сільського господарства і успішним втіленням його у життя стала діяльність управителів маєтків (сучасною термінологією - менеджерів). Зразковою у цьому плані можна назвати діяльність визначного на той період вченого і агронома-практика О. О. Ізмаїльського. Він відомий і як віце-президент Полтавського сгт (з 1883 р.), ініціатор створення Полтавського дослідного поля ${ }^{27}$. Вчений розробив методи боротьби з посухою, розкрив негативні наслідки людської діяльності у висушуванні степів, зміні клімату, запропонував вирішення проблеми збільшення врожайності сільськогосподарських культур, звернув увагу на заліснення ярів та створення полезахисних лісосмуг і т.п. О. О. Ізмаїльський працював управителем маєтку «Дячкове» князя С. В. Кочубея у Полтавській губернії. Він впровадив у господарство цього землевласника полезахисні лі- 
сосмуги, протиерозійні лісові насадження на схилах та ставки в гирлах балок і ярів, раціональне землевпорядження, багатопільні сівозміни з чистими парами та багаторічними злаково-бобовими травами, сортові посіви зернових та технічних культур, глибоку оранку та інші агрокультурні заходи. Вчений перетворив господарство на зразкове за урожайністю та прибутковістю.

Просвітництво. Статути тогочасних сгт закріплювали право на просвітницьку діяльність. Одною $з$ цілей аграрних організацій стало сприяння поширенню знань та передового досвіду. Власне просвітництво було найголовнішим для товариств. У Південно-Західному краї, через відсутність земств, така діяльність сгт набула особливого значення. Просвітницький напрям позашкільної освіти здійснювався товариствами через такі заходи: проведення аграрних виставок і з'їздів, курсів для фахівців та читань для сільського населення.

Одним із важливих заходів по розповсюдженню сільськогосподарських знань було заснування бібліотек, фондами яких могли б користуватися усі бажаючі. У Південно-Західному краї на 1915 рік 35 аграрних організацій краю відкрили спеціалізовані бібліотеки. Однісю з перших аграрних бібліотек варто вважати бібліотеку Київського сгт. У 1912 році вона налічувала 2760 примірників видань фахової літератури ${ }^{28}$. Подібні бібліотеки мали всі сгт українських губерній. Вони збільшували свої фонди за рахунок закупівлі та обміну книжками.

3 метою поширення фахових знань створювались спеціальні музеї. Станом на 1915 рік при сгт регіону працювало п'ять аграрних музеїв ${ }^{29}$. Кустарний музей був відкритий при Київському кустарному товаристві, зоологічний музей - при Київському товаристві дослідників природи. Музей «формових дерев» працював при Київському відділенні Імператорського Російського товариства плодівництва. Музеї бджільництва - при Боярській школі бджільництва I розряду Південно-Російського товариства бджільництва та сільському Беліловському товаристві бджільництва ${ }^{30}$.

Таким чином, зміни в економіці українських губерній Російської імперії др. пол. XIX ст. сприяли розквіту підприємництва, змушували покращувати і вдосконалювати сільськогосподарську техніку, опановувати нові прогресивні форми господарювання. Ці роки варто назвати періодом значного інтересу до становлення капіталістичної аграрної промисловості та перебудови основ сільського господарства. Даний процес зумовлений об'єктивним суспільно-політичним і соціально-економічним розвитком українських губерній. Розпочався він з заснування $c z m$, їхньої теоретичної і практичної діяльності. Відбувалося усвідомлення європейських аграрних ідей та досвіду, втілення їх у життя. Ініціативи громадських організацій були своєчасними і цілеспрямованими. У багатьох питаннях позиції сгт різних українських губерній збігалися.

Одним із важливих чинників розвитку аграрної освіти став європейський досвід. За взірець аграрних навчальних закладів брались німецькі школи. Мережа українських навчальних закладів відповідала потребам тогочасного суспільства та економіки. Передові представники сгт були готові до сприймання прогресивних ідей та втілення їх у життя. Набутий досвід був запроваджений зразкових господарствах. У деяких регіонах України приватна ініціатива випереджала державну.

Сгm перетворилися на центр розвитку наукових досліджень в агрономії. Сільськогосподарські дослідні установи стали посередницькою ланкою між наукою та практикою. Варто відмітити співпрацю громадських організацій, урядових структур та освітніх закладів. Просвітницька діяльність аграрних об‘єднань проявилася, передусім, у створенні фахової освіти. Крім того, сгт проводили виставки і з'їзди, організовували курси для спеціалістів та сільського населення, відкрили галузеві музеї і бібліотеки.

1 Зайкевич A. E. Опытные поля (Харьковского сельскохозяйственного общества за 18811888 гг.). Краткий отчет о результатах /А. Е. Зайкевич. Х., 1888. 80 с.; Ротмистров В. Г. Одесское опытное поле Императорского общества сельского хозяйства Южной России за 1904-1906 гг. Краткий отчет / В. Г. Ротмистров // Записки Императорского общества сельского хозяйства Южной России. Одесса. 1907. № 5-6. С. 1-96; Фурдуев В. Очерк возникновения и организации опытных сельскохозяйственных учреждений и проект устройства опытного поля при Полтавском сельскохозяйственнном обществе / В. Фурдуев. Полтава: Тип. И. А. Дохмана, 1882. 55 с.; Киевское общество 
сельского хозяйства и сельскохозяйственной промышленности с 1876 по 1901 год (Краткий отчет) / Сост. Т. Осадчий. К.: Тип. П. Барского, 1901. 120 с.

${ }^{2}$ Вергунов В. А. Перші кроки на шляху до інституту (До 100-річчя заснування Інституту землеробства Української академії аграрних наук / В. А. Вергунов // Зб. наук. праць Ордена Трудового Червоного Прапора Ін-ту землеробства УААН. К.: Нора-прінт, 2000. Вип. 3-4. С. 121-127; Гармаш Т. П. Портрети діячів природоохоронної справи: Полтавщина (XIX - поч. XX ст.): монографія / Т. П. Гармаш. Полтава: ТОВ «АСМІ», 2009. 196 с.; Костюк М. Діяльність Умансько-Липовецького сільськогосподарського товариства з популяризації сільськогосподарських знань позашкільним шляхом (початок ХХ ст.) / М. В. Костюк // Український селянин: Зб. наук. праць. Черкаси, 2006. Вип. 10. C. $140-143$.

${ }^{3}$ Общества сельскохозяйственные // Энциклопедический словарь / Сост. Ф. А. Брокгауз, И. А. Ефрон. СПб., 1900. Т. 29. Кн. 57. С. 416.

${ }^{4}$ Винер B. Организация опытных учреждений в Германии, Австро-Венгрии, Швейцарии и Царстве Польском. СПб.: Тип. «Сельского вестника», 1912. С. 39.

${ }^{5}$ Енкен Б. К. Развитие опытного дела в России и его современное положение / Б. К. Енкен. Полтава: Тип. Полтавского ОСХ, 1912. С. 12.

${ }^{6}$ Державний архів Харківської області. Ф. 304. Оп. 1. Спр. 2884. Арк. 2.

${ }^{7}$ Южнорусская сельскохозяйственная газета. 1906. 11 октября.

${ }^{8}$ Центральний державний історичний архів України, м. Київ. Ф. 442. Оп. 704. Спр. 47. Арк. 22.

9 Державний архів Одеської області. Ф. 22. Оп. 1. Спр. 284. Арк. 18.

${ }_{10}$ Вешняков В. Обзор сельскохозяйственных учреждений в Англии, Франции, Бельгии, Голландии, Германии и Италии. СПб.: Тип. Мин. земледелия, 1866. С. 34.

${ }_{11}$ Справочник по сельскохозяйственным опытным учреждениям России / Сост. А. Г. Дояренко. М.: Тип. О. Л. Сомовой, 1912. С. 372.

${ }_{12}$ Винер В. В. Сельскохозяйственное опытное дело / В. В. Винер. М.: Изд-во Наркомзема «Новая деревня», 1922. С. 6.

13 Державний архів Харківської області. Ф. 237. Оп. 1. Спр. 4. Арк. 115.

${ }_{14}$ Агрономическая помощь в России / Под ред. В. В. Морачевского. Пг.: Тип. В. Ф. Киршбаума, 1915. С. 28.

15 Державний архів Харківської області. Ф. 237. Оп. 1. Спр. 51. Арк. 30.

16 Чайка Н. Г. Становлення та розвиток наукових установ при сільськогосподарських товариствах Правобережної України (др. пол. XIX - поч. XX ст.): автореф. ... дис. канд. іст. наук. К., 2005. $20 \mathrm{c}$.

${ }^{17}$ Рибченко Д. В. Формування мережі та розвиток сільськогосподарських освітніх закладів Київщини у XIX - на поч. XX ст.: автореф. ... дис. канд. іст. наук. К., 2004. 20 с.

${ }^{18}$ Колісник $B$. Подільське товариство сільського господарства і сільськогосподарської промисловості. Історичний нарис (1896-1918рр.). Вінниця, 2007. С. 148.

19 Краткий обзор 12-летней деятельности Подольского общества сельского хозяйства и сельскохозяйственной промышленности (1898-1911 гг.) // Сост. Ф. Л. Любанский. Винница, 1911. С. 20.

20 Сведерский B. Положение селекционно-семенного дела в Подольской губернии // Экономическая жизнь Подолии. 1915. № 14. С. 19-20.

21 Запороженко А. П. Некоторые семенные хозяйства Юго-Западного края // Хозяйство. 1916. № 23. C. $415-416$.

22 Городецкий C. Исторический очерк развития опытных учреждений Подольской губернии. // Справочный листок Подольского общества сельского хозяйства и сельскохозяйственной промышленности. 1914. № 2. С. 58.

${ }^{23}$ Яропуд В. В. Історія подільського садівництва. Вінниця, 2002. С. 54.

24 Лец-Запартович И. Сеть коллективных опытов ПОСХ и главнейшие результаты ее деятельности (1900-1914 гг.) // Справочный листок Подольского общества сельского хозяйства и сельскохозяйственной промышленности. 1914. № 10. С. 4-5.

${ }^{25}$ Вербецкий К. Л. Труды сети опытных полей Полтавской губернии. / К. Л. Вербецкий. Вып. 1. Полтава, 1913. С. 25.

${ }^{26}$ Овсянников Б. А. Опытное поле // Труды Полтавской сельскохозяйственной станции. Полтава:

Тип. Д. Н. Подземского. 1914. № 22. С. 10.

27 Державний архів Харківської області. Ф. 304. Оп. 1. Спр. 2496. Арк. 71.

${ }_{28}$ Справочник по сельскохозяйственной периодической печати / Под ред. В. В. Морачевского.

Пг.: Тип. В. Ф. Киршбаума,1915. С. 36.

${ }^{29}$ Державний архів Житомирської області. Ф. 187. Оп. 1. Спр. 28. Арк. 3.

30 Державний історичний архів, м. Київ. Ф. 442. Оп. 703. Спр. 81. Арк. 20. 